Case Report

\title{
A Case of New-Onset Dermatomyositis in the Second Trimester of Pregnancy: A Case Report and Review of the Literature
}

\author{
Tayfun Akalin, ${ }^{1}$ Hatice Akkaya, ${ }^{2}$ Barış Büke, ${ }^{2}$ and İbrahim Koçak ${ }^{3}$ \\ ${ }^{1}$ Department of Internal Medicine, Section of Rheumatology, Kayseri Training and Research Hospital, 38020 Kayseri, Turkey \\ ${ }^{2}$ Department of Obstetrics and Gynecology, Kayseri Training and Research Hospital, 38020 Kayseri, Turkey \\ ${ }^{3}$ Department of Internal Medicine, Kayseri Training and Research Hospital, 38020 Kayseri, Turkey \\ Correspondence should be addressed to Tayfun Akalin; tayfunakalin@yahoo.com
}

Received 27 March 2016; Revised 20 May 2016; Accepted 30 May 2016

Academic Editor: Michael Geary

Copyright (c) 2016 Tayfun Akalin et al. This is an open access article distributed under the Creative Commons Attribution License, which permits unrestricted use, distribution, and reproduction in any medium, provided the original work is properly cited.

\begin{abstract}
Dermatomyositis (DM), a subtype of idiopathic inflammatory myopathies (IIMs), is characterized by skin rash, proximal muscle weakness, and inflammatory infiltrates in the muscle tissue. The peak incidence of the disease is at the age of 50-60 years, and only $14 \%$ of the patients with IIMs are estimated to present during reproductive years. Because of the limited pregnancy experience in patients with IIMs, little is known regarding the effects of DM on pregnancy or vice versa. We herein report a 40-year-old woman who developed DM in the second trimester of her pregnancy and did not respond to treatment with methylprednisolone. Her pregnancy was terminated at the 32nd week of gestation, due to preeclampsia and fetal distress. She delivered a healthy baby and improved rapidly after delivery. We have searched PubMed for relevant articles and reviewed previously published cases.
\end{abstract}

\section{Introduction}

Dermatomyositis (DM) is an idiopathic inflammatory myopathy (IIM) characterized by skin rash, proximal muscle weakness, and inflammatory infiltrates in the muscle tissue. It is a rare disease with an estimated prevalence of 11 cases per 100,000 individuals [1]. Although it may begin at any age, the peak incidence is at the age of 50-60 years. Only $14 \%$ of patients with IIMs are estimated to present during childbearing ages [2]. Therefore, pregnancy-associated cases are rare in the literature.

Little is known regarding the effects of DM on pregnancy or vice versa. Case reports and small series indicate that most patients with quiescent disease at conception remain inactive during pregnancy and have good pregnancy outcomes $[3,4]$, whereas preexisting active disease or onset of DM during pregnancy was reported to be associated with high frequency of fetal death and premature delivery [4]. Contrary to systemic lupus erythematosus (SLE), DM seems to remain inactive during pregnancy in most patients [3-5]. There are conflicting data as to whether pregnancy is a triggering factor for the development of DM $[3,6]$. Although corticosteroids are the mainstay of treatment and effective in most patients, some patients with DM are nonresponsive or intolerant to corticosteroids and treatment options in these patients are not clear.

We herein report a 40-year-old woman who developed $\mathrm{DM}$ in the second trimester of her pregnancy and did not respond to treatment with methylprednisolone. Her pregnancy was terminated at the 32 nd week of gestation due to preeclampsia and fetal distress. We have searched PubMed using the search terms "pregnancy", "dermatomyositis", and "idiopathic inflammatory myopathy" and reviewed relevant articles.

\section{Case Report}

A 40-year-old woman in the 27th week of her fourth pregnancy was referred to our rheumatology clinic because of a three-week history of a skin rash, arthralgia, and weak positive anti-nuclear antibody test by immunofluorescence assay (ANA-IFA). Her previous three pregnancies were uneventful. She did not have a history of recent infections nor a potential exposure to toxic or medical agents. Physical examination on 


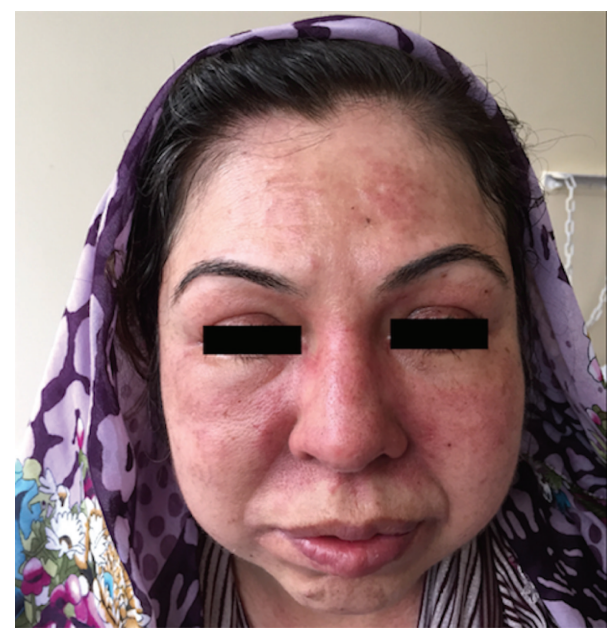

(a)

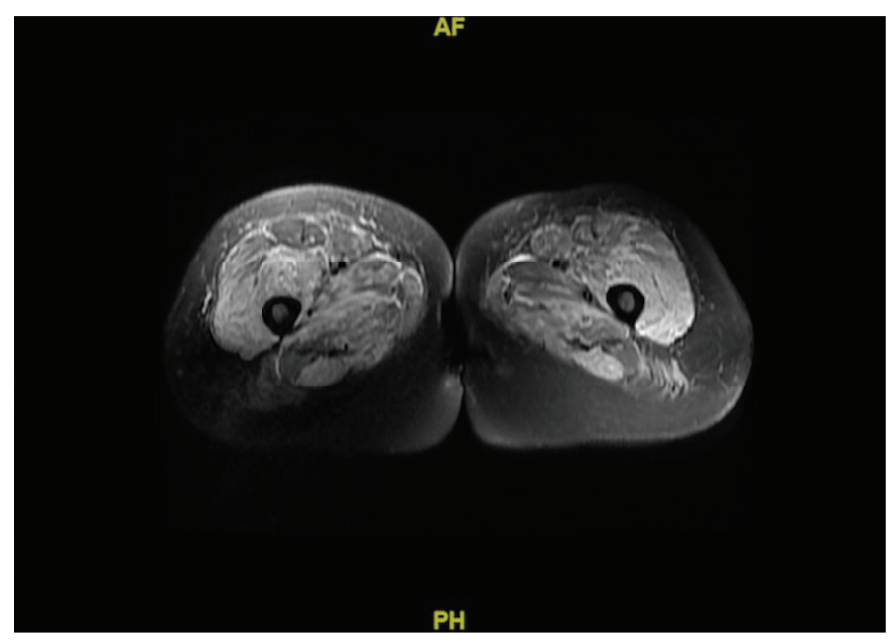

(b)

FIGURE 1: Skin and muscle involvement: (a) rash on her face and (b) bilateral diffuse inflammation in thigh muscles (magnetic resonance imaging).

admission revealed bilateral periorbital edema and erythema on her eyelids (heliotrope rash) as well as diffuse rash on the face (Figure 1(a)). She had bilateral erythematous macules on the extensor surfaces of the metacarpophalangeal and proximal interphalangeal joints (Gottron's sign). There was also symmetrical and proximal muscle weakness in the upper and lower extremities. Other physical examination findings were unremarkable. Laboratory findings were as follows: serum creatine kinase (CK): $2138 \mathrm{U} / \mathrm{L}$ (normal: 29-200), lactate dehydrogenase: 520 U/L (normal: 140-280), aspartate aminotransferase: $113 \mathrm{U} / \mathrm{L}$ (normal: <35), and alanine aminotransferase: $58 \mathrm{U} / \mathrm{L}$ (normal: <35). ANA-IFA was weakly positive at 1/100 titration (homogenous pattern). Anti-Ro52 was positive, but antibodies to Jo-1 or other extractable nuclear antigens were negative. Serum anti-double stranded DNA, rheumatoid factor, and complement levels were within normal ranges. Serum creatinine level and urine analysis were normal. Erythrocyte sedimentation rate was $31 \mathrm{~mm} / \mathrm{h}$ and serum C-reactive protein level was $17.9 \mathrm{mg} / \mathrm{L}$ (normal 0-5). Electromyography of the right deltoid muscle revealed fibrillations and small polyphasic motor unit action potentials. Magnetic resonance imaging showed diffuse edema in thigh muscles (Figure 1(b)). She declined muscle biopsy. Investigations for occult malignancies including breast ultrasound, pelvic and abdominal ultrasound, peripheral blood smear, and fecal occult blood test were all negative. Serum CA-125 level was $6.5 \mathrm{U} / \mathrm{mL}$ (normal 0-35). She was diagnosed with dermatomyositis according to Bohan and Peter's criteria [27, 28] and started on methylprednisolone $32 \mathrm{mg}$ /day orally. Five weeks later, however, no improvement was noted in muscle strength, skin rash, or serum CK level. Her blood pressure was 180/120 $\mathrm{mmHg}$ and she had developed bilateral pretibial edema. She was diagnosed as having preeclampsia and her pregnancy was terminated by an emergency caesarean section at the 32 nd week of the gestation. She gave birth to a $1800 \mathrm{~g}$ male infant with no apparent congenital malformation.
In postpartum period, we searched the mother for the presence of anti-phospholipid antibodies. Anti-cardiolipin and anti- $\beta 2$ glycoprotein-1 antibodies (immunoglobulin $\mathrm{G}$ and $\mathrm{M}$ isotypes) were found to be negative. Lupus anticoagulant test could not be performed due to technical limitations.

After delivery, her muscle strength and rash improved rapidly. The dosage of methylprednisolone was tapered off. At postpartum 6th week, she was on methylprednisolone $8 \mathrm{mg} /$ day and serum CK levels were within normal limits. There was only mild facial rash left, but heliotrope rash and Gottron's sign had completely resolved.

\section{Discussion}

DM in pregnant patients may be present before the onset of pregnancy, occur during pregnancy, or develop in postpartum period [4]. Table 1 summarizes the pregnancies with DM [2-4, 6-26]. There are 53 pregnancies in 41 patients. The onset of DM was before pregnancy in 21 patients, during pregnancy in 16 , and in puerperal period in 4 .

Gutierrez et al. [6] reported 18 female patients with IIMs (2 polymyositis-PM, 16 DM). Four of these patients (22\%) had developed DM/PM in pregnancy-related period (3 in pregnancy, 1 in postpartum period), and they speculated that pregnancy was a precipitating factor in the onset of inflammatory myositis. However, a recent retrospective cohort study [3] with 41 patients with DM showed that only in one patient (2.4\%) did the disease begin in the pregnancy-related period (i.e., during pregnancy or in puerperal period). Furthermore, the observed and expected proportions of IIM patients with the onset of disease in pregnancy-related period were similar (3.9\% versus $3.7 \%$, resp.). In a case series with 78 female patients with DM, no patient was identified with the onset of her disease during pregnancy or in postpartum period [10]. Moreover, in another case series with 173 female patients with $\mathrm{DM} / \mathrm{PM}$, only one patient had disease onset during 
TABLE 1: Dermatomyositis complicating pregnancy. Review of the cases.

\begin{tabular}{|c|c|c|c|c|c|c|}
\hline Author [ref.] & Patient & $\begin{array}{c}\text { Age at } \\
\text { diagnosis } \\
\text { (years) }\end{array}$ & DM onset & $\begin{array}{c}\text { Disease activity } \\
\text { (during pregnancy) }\end{array}$ & Treatment & Fetal outcome \\
\hline Glickman [7] & 1 & 27 & $\mathrm{BP}$ & Improved & Prednisone & Healthy \\
\hline \multirow{2}{*}{ Masse [8] } & \multirow[t]{2}{*}{1} & \multirow[t]{2}{*}{26} & \multirow[t]{2}{*}{$\mathrm{BP}$} & Improved & ACTH & Healthy \\
\hline & & & & Inactive & ACTH & Abortion \\
\hline Tsai et al. [9] & 1 & 33 & DP & Active & No treatment & Neonatal death \\
\hline \multirow{9}{*}{ Gutierrez et al. [6] } & 1 & $\mathrm{NI}$ & DP & Active & Prednisone & Abortion \\
\hline & 2 & NI & DP & Active & Prednisone & Stillbirth \\
\hline & \multirow[t]{2}{*}{3} & \multirow[t]{2}{*}{ JDM } & \multirow[t]{2}{*}{$\mathrm{BP}$} & Inactive & No treatment & Abortion \\
\hline & & & & Exacerbation & Prednisone & Premature \\
\hline & \multirow[t]{2}{*}{4} & \multirow[t]{2}{*}{ NI } & \multirow[t]{2}{*}{$\mathrm{PP}$} & Inactive & No treatment & Abortion \\
\hline & & & & Inactive & No treatment & Caesarean at term \\
\hline & 5 & NI & $\mathrm{BP}$ & Inactive & No treatment & Healthy \\
\hline & \multirow[t]{2}{*}{6} & \multirow[t]{2}{*}{$\mathrm{NI}$} & \multirow[t]{2}{*}{$\mathrm{BP}$} & Exacerbation & Prednisone & Premature \\
\hline & & & & Inactive & No treatment & $\begin{array}{c}\text { Twins } \\
\text { Premature/neonatal } \\
\text { death }\end{array}$ \\
\hline \multirow{5}{*}{ King and Chow [10] } & \multirow[t]{2}{*}{1} & \multirow[t]{2}{*}{12} & \multirow[t]{2}{*}{$\mathrm{BP}$} & Inactive & No treatment & IUGR \\
\hline & & & & Inactive & No treatment & Healthy \\
\hline & \multirow[t]{2}{*}{2} & \multirow[t]{2}{*}{20} & \multirow[t]{2}{*}{$\mathrm{BP}$} & Inactive & No treatment & Healthy \\
\hline & & & & Inactive & No treatment & Healthy \\
\hline & 3 & 25 & $\mathrm{BP}$ & Exacerbation & Prednisone & Healthy \\
\hline England et al. [11] & 1 & 35 & DP & Active & Steroid & IUGR \\
\hline \multirow{2}{*}{ Ishii et al. [12] } & \multirow[t]{2}{*}{1} & \multirow[t]{2}{*}{31} & \multirow[t]{2}{*}{ DP } & Active & Steroid & Healthy \\
\hline & & & & Inactive & Steroid & Healthy \\
\hline Pinheiro Gda et al. [2] & 1 & 14 & DP & Active & Steroid & Healthy \\
\hline Suwa et al. [13] & 1 & 29 & $\mathrm{PP}$ & - & $\begin{array}{l}\text { Spontaneous } \\
\text { remission }\end{array}$ & - \\
\hline Harris et al. [14] & 1 & 29 & DP & Active & $\begin{array}{c}\text { Induced labor, pulse } \\
\text { steroid PP }\end{array}$ & Healthy \\
\hline Solomon and D'Alton [15] & 1 & 28 & DP & Active & Steroid & Healthy \\
\hline Kofteridis et al. [16] & 1 & 25 & DP & Active & Pulse steroid & Abortion \\
\hline Kanoh et al. [17] & 1 & 33 & $\mathrm{PP}$ & - & Prednisolone PP & - \\
\hline Lee and Yoo [18] & 1 & 33 & $\mathrm{PP}$ & - & $\begin{array}{c}\text { Methylprednisolone } \\
\text { PP }\end{array}$ & - \\
\hline \multirow{2}{*}{ Silva et al. [4] } & 1 & 22 & $\mathrm{BP}$ & Active, no change & Steroid, MTX & Abortion \\
\hline & 2 & 28 & $\mathrm{BP}$ & Inactive & Prednisolone & Healthy \\
\hline Park et al. [19] & 1 & 22 & DP & Active & $\begin{array}{c}\text { Therapeutic abortion, } \\
\text { IVIG PP }\end{array}$ & Abortion \\
\hline Mosca et al. [20] & 1 & 32 & DP & Active & $\begin{array}{c}\text { Methylprednisolone, } \\
\text { IVIG }\end{array}$ & Healthy \\
\hline Pasrija et al. [21] & 1 & 27 & DP & Active & $\begin{array}{c}\text { Dexamethasone, } \\
\text { HCQ }\end{array}$ & Healthy \\
\hline & 1 & 22 & $\mathrm{BP}$ & Inactive & Methylprednisolone & Healthy \\
\hline & & & & Inactive & Methylprednisolone & Abortion \\
\hline Váncsa et al [22] & 2 & 28 & $\mathrm{BP}$ & Inactive & Methylprednisolone & Healthy \\
\hline V antesa cl ai. $[22]$ & 3 & 33 & $\mathrm{BP}$ & Inactive & No treatment & Healthy \\
\hline & 4 & 37 & DP & Active & Methylprednisolone & Premature \\
\hline & 5 & 30 & $\mathrm{BP}$ & Inactive & No treatment & Healthy \\
\hline
\end{tabular}


TABle 1: Continued.

\begin{tabular}{|c|c|c|c|c|c|c|}
\hline Author [ref.] & Patient & $\begin{array}{c}\text { Age at } \\
\text { diagnosis } \\
\text { (years) }\end{array}$ & DM onset & $\begin{array}{c}\text { Disease activity } \\
\text { (during pregnancy) }\end{array}$ & Treatment & Fetal outcome \\
\hline \multirow{2}{*}{ Chopra et al. [23] } & \multirow[t]{2}{*}{1} & \multirow[t]{2}{*}{28} & \multirow[t]{2}{*}{$\mathrm{BP}$} & Inactive & No treatment & Healthy \\
\hline & & & & Inactive & No treatment & IUGR \\
\hline Nozaki et al. [24] & 1 & 31 & $\mathrm{DP}$ & Active & $\begin{array}{c}\text { Prednisolone, IVIG } \\
\text { PP }\end{array}$ & Premature \\
\hline Linardaki et al. [25] & 1 & 42 & $\mathrm{DP}$ & Active & $\begin{array}{c}\text { Methylprednisolone, } \\
\text { IVIG }\end{array}$ & Healthy \\
\hline Madu et al. [26] & 1 & JDM & $\mathrm{BP}$ & Exacerbation & Prednisolone & Healthy \\
\hline \multirow{12}{*}{ Pinal-Fernandez et al. [3] } & \multirow[t]{3}{*}{1} & \multirow[t]{3}{*}{35} & \multirow[t]{3}{*}{$\mathrm{BP}$} & Improvement & Prednisone, MTX & Induced abortion \\
\hline & & & & Improvement & Prednisone & Healthy \\
\hline & & & & Improvement & Prednisone & Healthy \\
\hline & \multirow[t]{2}{*}{2} & \multirow[t]{2}{*}{35} & \multirow[t]{2}{*}{$\mathrm{BP}$} & Improvement & Prednisone & Healthy \\
\hline & & & & Improvement & Prednisone & Healthy \\
\hline & \multirow[t]{3}{*}{3} & \multirow[t]{3}{*}{38} & \multirow[t]{3}{*}{$\mathrm{BP}$} & Improvement & Prednisone & $\begin{array}{l}\text { Induced abortion } \\
\text { (anencephaly) }\end{array}$ \\
\hline & & & & Improvement & Prednisone & Healthy \\
\hline & & & & Improvement & Prednisone & Healthy \\
\hline & 4 & 32 & $\mathrm{PP}$ & - & Prednisone PP & - \\
\hline & \multirow[t]{2}{*}{5} & \multirow[t]{2}{*}{31} & \multirow[t]{2}{*}{$\mathrm{BP}$} & Asymptomatic & No treatment & Healthy \\
\hline & & & & Asymptomatic & No treatment & Abortion \\
\hline & 6 & 36 & $\mathrm{BP}$ & No change & Prednisone & Healthy \\
\hline Present case & 1 & 40 & $\mathrm{DP}$ & Active & Methylprednisolone & Premature \\
\hline
\end{tabular}

$\mathrm{BP}$, before pregnancy; DP, during pregnancy; PP, puerperal period; NI, not indicated; JDM, juvenile dermatomyositis; ACTH, adrenocorticotrophic hormone; IVIG, intravenous immunoglobulin; MTX, methotrexate; HCQ, hydroxychloroquine; IUGR, intrauterine growth restriction.

TABLE 2: Pregnancy outcomes in active and inactive DM.

\begin{tabular}{|c|c|c|c|c|}
\hline \multirow[b]{2}{*}{ Pregnancy outcomes } & \multicolumn{2}{|c|}{ Disease activity during pregnancy } & \multirow[b]{2}{*}{$p$ value ${ }^{*}$} & \multirow[b]{2}{*}{ OR $(95 \%$ CI $)$} \\
\hline & Active $(n=21)(\%)$ & $\begin{array}{l}\text { Inactive }(n=32)(\%) \\
\quad(1 \text { pair of twins })\end{array}$ & & \\
\hline Healthy & $9(42.8)$ & $22(66.7)$ & NS & $0.38(0.12-1.16)$ \\
\hline Premature birth & $5(23.8)$ & $1(3.0)$ & 0.028 & $10.00(1.08-92.94)$ \\
\hline IUGR & $1(4.8)$ & $2(6.1)$ & NS & $0.78(0.07-9.12)$ \\
\hline Abortion & $4(19)$ & $7(21.2)$ & NS & $0.87(0.22-3.44)$ \\
\hline Stillbirth & $1(4.8)$ & $0(0)$ & NS & - \\
\hline Neonatal death & $1(4.8)$ & $1(3.0)$ & NS & $1.60(0.10-27.04)$ \\
\hline Total fetal loss** & $6(28.6)$ & $8(24.2)$ & NS & $1.25(0.36-4.31)$ \\
\hline
\end{tabular}

${ }^{*}$ Chi-square or Fisher's exact test used where appropriate. $p<0.05$ is considered to be statistically significant.

${ }^{* *}$ Sum of the abortions, stillbirths, and neonatal deaths.

DM, dermatomyositis; OR, odds ratio; NS, not significant; IUGR, intrauterine growth restriction.

pregnancy [22]. It seems that pregnancy is not a triggering factor for the development of DM.

Pregnancy outcomes in DM are shown in Table 2 (derived from Table 1). There are 6 (11.1\%) premature babies, $11(20.4 \%)$ abortions, and $3(5.6 \%)$ intrauterine growth restrictions (IUGR) in 53 pregnancies (1 pair of twins). Patients with active disease have more frequent preterm birth compared to inactive patients $(23.8 \%$ versus $3 \%, p=0.028)$. Relative frequencies of total fetal loss and IUGR in patients with active disease are similar to those in inactive patients (28.6\% versus $24.2 \%$ and $4.8 \%$ versus $6.1 \%$, resp.).

It is controversial whether pregnancy is a risk factor for exacerbation of DM. In a case series, exacerbation occurred in 3 of 7 pregnancies (43\%) and pregnancy was considered as a precipitating factor for DM activation [6]. In another case series, however, no exacerbation was observed in 11 pregnancies; DM improved in 8 pregnancies and remained inactive in the other three [3]. Review of the published 
cases indicates only four DM exacerbations $[6,10,26]$ in 37 pregnancies (10.8\%). This flare rate is markedly less frequent than that reported in pregnant patients with SLE (57\%) [5].

Our case did not respond to moderate dose steroid during pregnancy. Nonresponsiveness to corticosteroid treatment during pregnancy and rapid improvement after delivery suggest that pregnancy-related factors such as hormonal changes or fetal antigen transfer to the mother during pregnancy may have been involved in the pathogenesis in this patient [29]. However, it should be noted that, in addition to pregnancy-related factors, inadequate steroid dose could also be responsible for treatment failure in our patient.

Corticosteroids are relatively safe drugs during pregnancy and are the first choice of treatment in pregnant patients with DM. However, some patients are nonresponsive or intolerant to corticosteroids [20]. Treatment options in this group of patients are not clear. Four patients were treated with IVIG either during pregnancy $[20,25]$ or in postpartum period $[19,24]$. IVIG treatments were successful in all patients. Babies were born at term and healthy. No patient was treated with other immunosuppressive drugs such as azathioprine or cyclosporine. Inadvertent methotrexate use resulted in abortions in two patients $[3,4]$.

In conclusion, pregnancy does not seem to be a triggering factor for the development of DM. In most patients, DM improves or remains inactive during pregnancy. Active disease and/or its treatment may be associated with preterm birth and/or preeclampsia. IVIG should be considered as a therapeutic option in steroid resistant/intolerant pregnant patients, especially if delivery is not a feasible option.

\section{Consent}

The patient has given informed consent for the case report to be published.

\section{Competing Interests}

The authors declare that they have no competing interests.

\section{References}

[1] L. Iaccarino, A. Ghirardello, S. Bettio et al., "The clinical features, diagnosis and classification of dermatomyositis," Journal of Autoimmunity, vol. 48-49, pp. 122-127, 2014.

[2] R. Pinheiro Gda, J. Goldenberg, E. Atra, R. B. Pereira, L. Camano, and B. Schmidt, "Juvenile dermatomyositis and pregnancy: report and literature review," The Journal of Rheumatology, vol. 19, no. 11, pp. 1798-1801, 1992.

[3] I. Pinal-Fernandez, A. Selva-O'Callaghan, A. Fernandez-Codina et al., "Pregnancy in adult-onset idiopathic inflammatory myopathy': report from a cohort of myositis patients from a single center," Seminars in Arthritis and Rheumatism, vol. 44, no. 2, pp. 234-240, 2015.

[4] C. A. Silva, S. M. Sultan, and D. A. Isenberg, "Pregnancy outcome in adult-onset idiopathic inflammatory myopathy," Rheumatology, vol. 42, no. 10, pp. 1168-1172, 2003.

[5] E. Borella, A. Lojacono, M. Gatto et al., "Predictors of maternal and fetal complications in SLE patients: a prospective study," Immunologic Research, vol. 60, no. 2-3, pp. 170-176, 2014.
[6] G. Gutierrez, R. Dagnino, and G. Mintz, "Polymyositis/dermatomyositis and pregnancy," Arthritis \& Rheumatism, vol. 27, no. 3, pp. 291-294, 1984.

[7] F. S. Glickman, "Dermatomyositis associated with pregnancy," United States Armed Forces Medical Journal, vol. 9, no. 3, pp. 417425, 1958.

[8] M. R. Masse, "Pregnancies and dermatomyositis," Bulletin de la Société Française de Dermatologie et de Syphiligraphie, vol. 69, pp. 921-923, 1962.

[9] A. Tsai, M. D. Lindheimer, and S. I. Lamberg, "Dermatomyositis complicating pregnancy," Obstetrics and Gynecology, vol. 41, no. 4, pp. 570-573, 1973.

[10] C. R. King and S. Chow, "Dermatomyositis and pregnancy," Obstetrics \& Gynecology, vol. 66, no. 4, pp. 589-592, 1985.

[11] M. J. England, T. Perlmann, and Y. Veriava, "Dermatomyositis in pregnancy: a case report," Journal of Reproductive Medicine for the Obstetrician and Gynecologist, vol. 31, no. 7, pp. 633-636, 1986.

[12] N. Ishii, H. Ono, T. Kawaguchi, and H. Nakajima, "Dermatomyositis and pregnancy. Case report and review of the literature," Dermatologica, vol. 183, no. 2, pp. 146-149, 1991.

[13] A. Suwa, M. Hirakata, K. Tsuzaka et al., "Spontaneous remission of dermatomyositis which developed one month after normal delivery," Ryumachi, vol. 32, no. 1, pp. 73-79, 1992.

[14] A. Harris, M. Webley, M. Usherwood, and S. Burge, "Dermatomyositis presenting in pregnancy," British Journal of Dermatology, vol. 133, no. 5, pp. 783-785, 1995.

[15] J. E. Solomon and M. E. D’Alton, "Dermatomyositis in pregnancy," Current Opinion in Obstetrics and Gynecology, vol. 8, no. 1, pp. 83-86, 1996.

[16] D. P. Kofteridis, P. I. Malliotakis, F. Sotsiou, N. K. Vardakis, L. N. Vamvakas, and D. S. Emmanouel, "Acute onset of dermatomyositis presenting in pregnancy with rhabdomyolysis and fetal loss," Scandinavian Journal of Rheumatology, vol. 28, no. 3, pp. 192-194, 1999.

[17] H. Kanoh, T. Izumi, M. Seishima, M. Nojiri, Y. Ichiki, and Y. Kitajima, "A case of dermatomyositis that developed after delivery: the involvement of pregnancy in the induction of dermatomyositis," British Journal of Dermatology, vol. 141, no. 5, pp. 897-900, 1999.

[18] S. I. Lee and W. H. Yoo, "Postpartum-onset dermatomyositis: case report and literature review," Modern Rheumatology, vol. 12, no. 4, pp. 362-365, 2002.

[19] I. W. Park, Y. J. Suh, J. H. Han et al., "Dermatomyositis developing in the first trimester of pregnancy," The Korean Journal of Internal Medicine, vol. 18, no. 3, pp. 196-198, 2003.

[20] M. Mosca, F. Strigini, A. Carmignani, A. D’Ascanio, A. R. Genazzani, and S. Bombardieri, "Pregnant patient with dermatomyositis successfully treated with intravenous immunoglobulin therapy," Arthritis Care \& Research, vol. 53, no. 1, pp. 119-121, 2005.

[21] S. Pasrija, R. Rana, K. Sardana, and S. S. Trivedi, "A case of autoimmune myopathy in pregnancy," Indian Journal of Medical Sciences, vol. 59, no. 3, pp. 109-112, 2005.

[22] A. Váncsa, A. Ponyi, T. Constantin, M. Zeher, and K. Dankó, "Pregnancy outcome in idiopathic inflammatory myopathy," Rheumatology International, vol. 27, no. 5, pp. 435-439, 2007.

[23] S. Chopra, V. Suri, R. Bagga, M. R. Thami, A. Sharma, and P. Bambery, "Autoimmune inflammatory myopathy in pregnancy," The Medscape Journal of Medicine, vol. 10, no. 1, article 17, 2008. 
[24] Y. Nozaki, S. Ikoma, M. Funauchi, and K. Kinoshita, "Respiratory muscle weakness with dermatomyositis during pregnancy: successful treatment with intravenous immunoglobulin therapy," Journal of Rheumatology, vol. 35, no. 11, p. 2289, 2008.

[25] G. Linardaki, E. Cherouvim, G. Goni, and K. A. Boki, "Intravenous immunoglobulin treatment for pregnancy-associated dermatomyositis," Rheumatology International, vol. 31, no. 1, pp. 113-115, 2011.

[26] A. E. Madu, E. Omih, E. Baguley, and S. W. Lindow, "Juvenile dermatomyositis in pregnancy," Case Reports in Obstetrics and Gynecology, vol. 2013, Article ID 890107, 3 pages, 2013.

[27] A. Bohan and J. B. Peter, "Polymyositis and dermatomyositis (first of two parts)," The New England Journal of Medicine, vol. 292, no. 7, pp. 344-347, 1975.

[28] A. Bohan and J. B. Peter, "Polymyositis and dermatomyositis (second of two parts)," The New England Journal of Medicine, vol. 292, no. 8, pp. 403-407, 1975.

[29] J. L. Nelson, "Pregnancy immunology and autoimmune disease," The Journal of Reproductive Medicine, vol. 43, no. 4, pp. 335-340, 1998. 


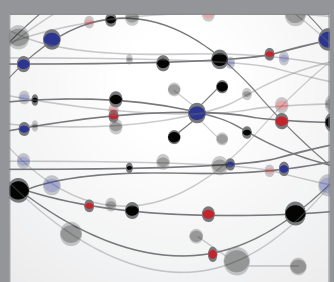

The Scientific World Journal
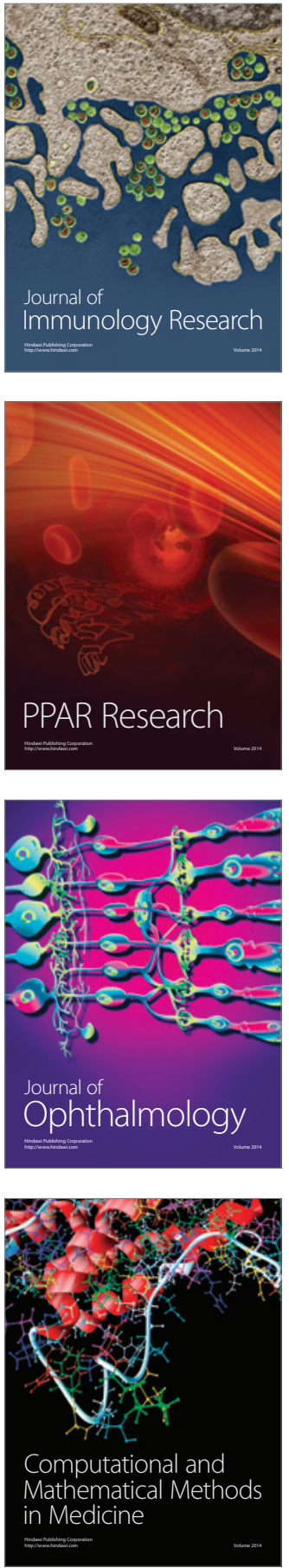

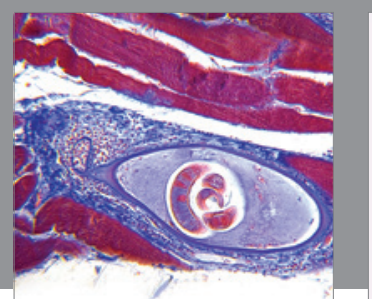

Gastroenterology Research and Practice

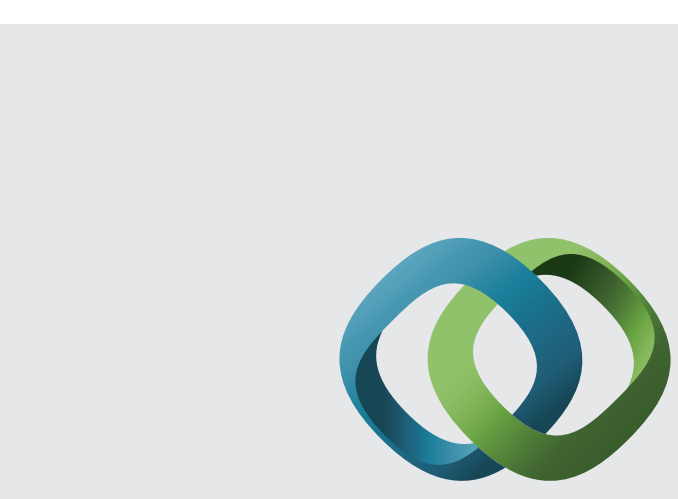

\section{Hindawi}

Submit your manuscripts at

http://www.hindawi.com
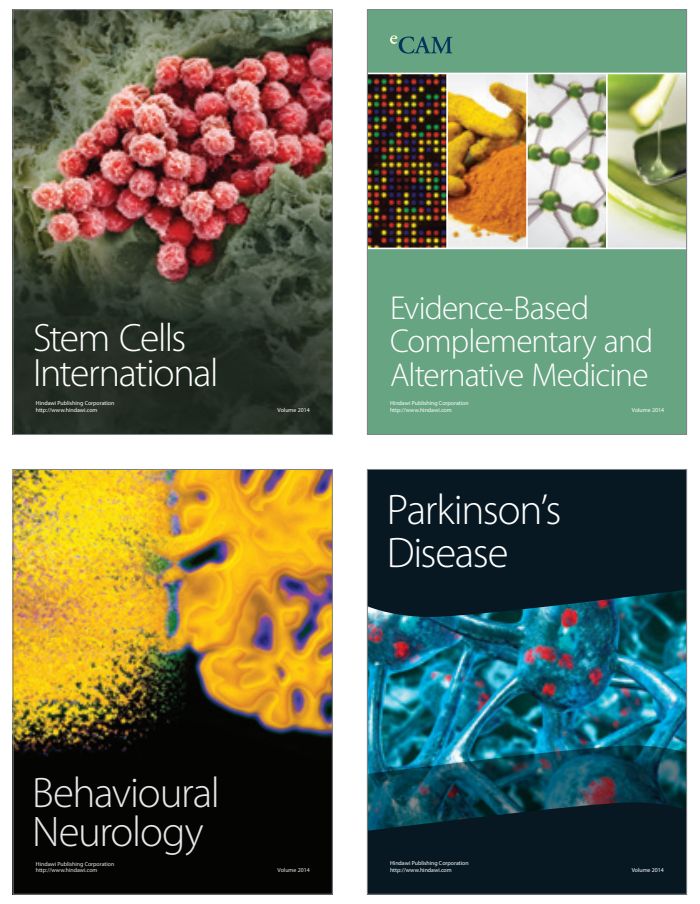
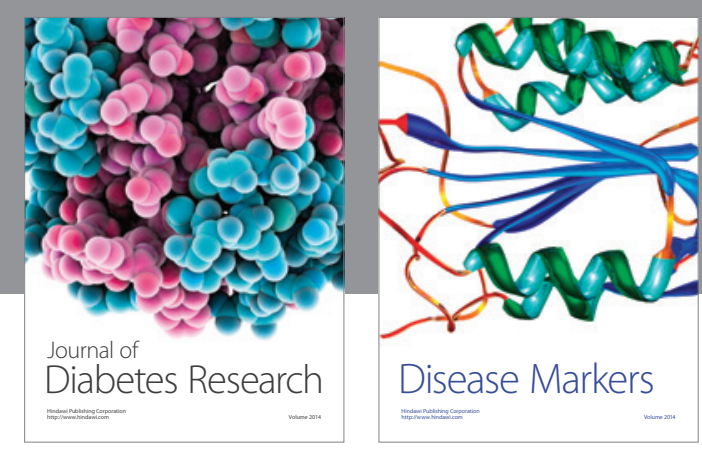

Disease Markers
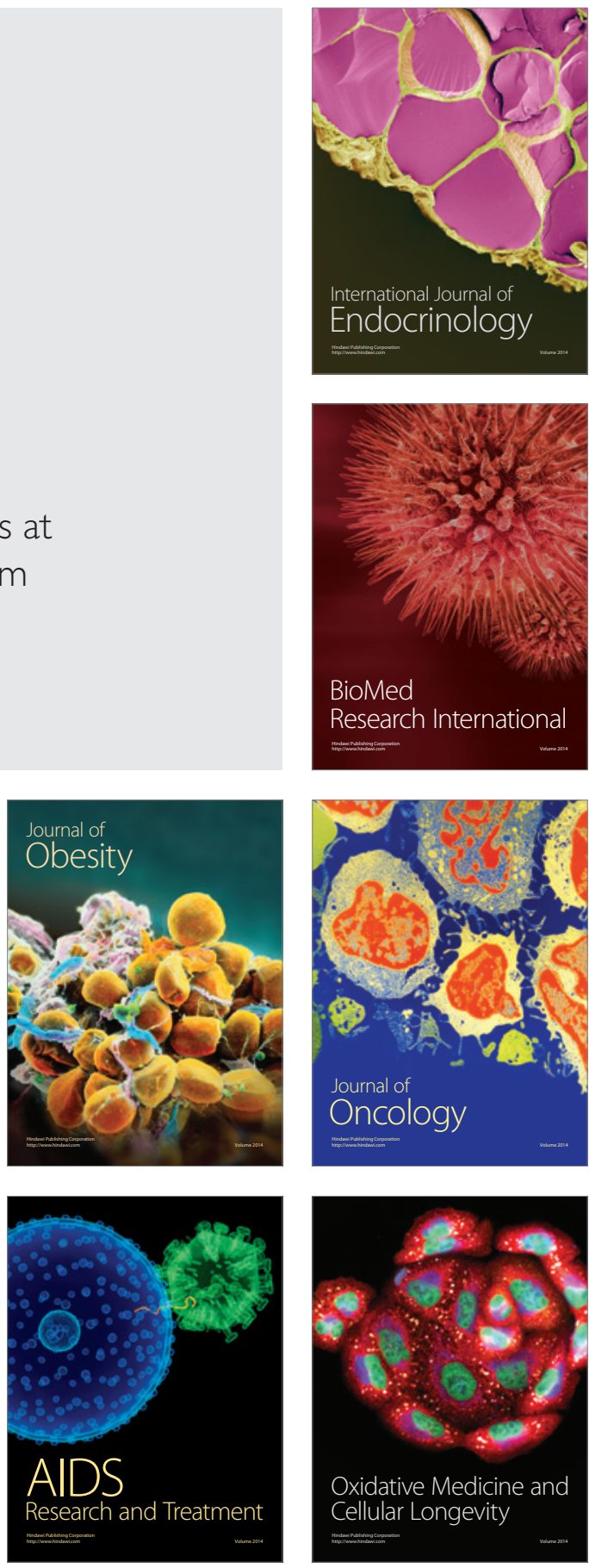